\title{
Ukrainian Village Weddings; Collected in Central Ukraine, 1998
}

\author{
Natalie Kononenko, University of Virginia
}

The Ukrainian village wedding is a complex affair with many important functions. It cements the union between the bride and the groom, establishing them as a new unit which will help perpetuate not only their respective families, but the whole village. The wedding contains fertility symbols to insure that the couple will bear children. It serves to honor the parents who reared the young people about to wed. Just as the wedding serves many functions, so it contains many moods. There is solemn religious expression and there is a great deal of frivolity and merry-making. The revelry that is part of the wedding is itself multifunctional. It balances the solemnity of the serious part of the wedding and the rigors of farming, bringing all participants, which often means a good part of the village, closer together. It subverts the normal order of life in the village, permitting theft, open eroticism, and disrespect for people in authority. It also contains ancient sacrificial overtones which actually emphasize the value of certain authority figures, specifically the parents. I will concentrate on the role of the parents in the wedding and especially in the tsyhanshchyna or "gypsy fest," the day of revelry, which follows the wedding proper. The tsyhanshchyna, during which the parents are abused, serves both to subvert the power of the parents and to confirm it. Furthermore, what is done to the parents has many of the elements of an agrarian festival, a ritual to insure crop fertility. Thus the wedding, a pivotal ritual in Ukrainian culture, reaches beyond the family and the village and tries to affect nature itself.

I collected materials in Central Ukraine, specifically Cherkas'ka oblast and Kyivs'ka oblast, in the summer and fall of 1998.(1) The description of the wedding which follows is based primarily on my field work. There is a great deal of variation from village to village and even greater variation between regions. Still, the weddings I witnessed share a basic structure with weddings across Ukraine. Contemporary village weddings in Central Ukraine last two to three days and may be abbreviated versions of weddings celebrated in the past. Some older people complained that today's youth fail to perform all of the steps of the wedding. By the same token, I saw great interest in reviving what people understood to be traditional and pre-Soviet and in performing the wedding in its full form, including wearing traditional vyshyvanka (embroidered Ukrainian clothing) instead of the western-style white gown with veil. An interesting compromise is to wear the white gown and veil for the civil part of the marriage ceremony (the registration of the marriage contract) and to wear 
Ukraimian clothing for all steps of the wedding celebrated in the home.(2)

The traditional wedding in Central Ukraine starts with a formal engagement. The groom and several respected elders, usually two older married men called starosty (elders), visit the home of the bride and make a request to her parents for her hand in marriage. This visit, variously called dohliadyny (viewing), domovyny (agreement), and other terms, involves an exchange of gifts. The groom's side provides a bottle of horilka (vodka) and the bride drapes the starosty with rushnyky (ritual towels). Each side gives the other a loaf of bread. Many Ukrainian-Americans and urban dwellers in Ukraine have reported hearing that a bride could reject her suitors by giving them a harbuz (pumpkin) instead of a loaf of bread. However, in real life, this seldom occurs because the young man and young woman had already courted and agreed to wed before the formal domovyny with their elders.(3)

The length of the engagement varies. One week is usually considered the minimum because that is the amount of time necessary for cooking and other preparations. The ritual part of the marriage process begins on the Thursday or Friday before the actual wedding with the baking of a special, semi-sweet bread called a korovai. On Saturday, or on Friday and Saturday morning if there are many guests, the bride and groom, often accompanied by a friend, the druzhka in the case of the bride and the boiaryn in the case of the groom, walk the village with a smaller, usually round ritual bread, called a shyshka, each summoning his and her respective wedding guests. On Friday evening the unmarried female friends of the bride gather for the devich vechir (girls' evening). During the devich vechir, the bride bids farewell to her friends and together they make the hiltse, usually a pine branch which is decorated with ribbons, berries, and "flowers" made out of ears of wheat arranged in a circle. The hiltse is used to grace the table during the wedding meals. Saturday is the day for signing the civil marriage contract. Sunday is the day for the church service, if there is one. The main ritual, whether the civil or the church ceremony, is followed by a separation of the couple and the fetching of the bride by the groom's wedding train. In most cases, the groom takes the bride back to her own home and leaves her there, returning with his friends and family to his own house. A meal is served at each house, after which the mother of the groom dispatches him and a special poizd ("train") to the home of the bride. This train is met with mock resistance, especially at the gates of the bride's house, and the groom has to pay a ransom, usually horilka and small amounts of money. After the ritual resistance, the groom's wedding train is admitted. In the house, small children demand money of the groom and then permit him to join the bride's family at the table. A more elaborate meal is served and the bride's korovai is cut and distributed; the guests offer gifts to the bridal couple in exchange for 
horilka and pieces of the korovai. After the meal, the whole wedding party travels to the groom's home for more food, drink, and dancing. Often, this trip back includes the ceremonial delivery of the bride's wedding chest, called a sunduk or skrynia, and a ritual procession with a special pair of icons draped in rushnyky. The meal at the groom's house concludes with the cutting the groom's korovai. It is distributed among the guests along with horilka and, as at the bride's house, all of the guests offer gifts to the couple when they accept their horilka and korovai. The morning after, there is a ceremonial breakfast for the bridal couple, sometimes accompanied by remnants of proofs of virginity, such as the presentation of a red kerchief by the groom to his best man. This kerchief is then hung on the roof or the gate.(4).

The parents assume prominent roles throughout the wedding process. To list some of the most important points: for the couple to be engaged, an agreement between the bride and groom is considered insufficient and a formal request must be addressed to the parents. Parents are in charge of the wedding preparations. It is the mother of the bride and the mother of the groom who summon women to bake the korovai and the shyshky. When the bride and groom issue invitations, they often go to the opposite parents and godparents first, that is, the bride invites the groom's parents and godparents and he invites hers. In the civil or church ceremonies, the mother of the bride and the mother of the groom spread out the rushnyk on which the couple will stand for their wedding vows. After the vows, the bride and groom bow to both sets of parents and often to the godparents. The mother of the bride ties the couple's hands together and leads them off the stage after a civil wedding. At the home of the groom, it is his mother who dispatches the wedding train and, at the home of the bride, her mother blesses the couple, ties their hands together once more, and leads them to the car or wagon which will take them to the groom's household. The groom's parents greet the new couple when they arrive and, at both houses, it is the parents who begin the gift-giving and the expression of good wishes to the couple which concludes ceremonial meals.

The solemn part of the wedding is followed by a period of frivolity variously called kury (chickens), tsyhani (gypsies), tsyhanshchyna (gypsy fest), or vechirky (evening party, though the festivities last all day). It can take the form of a day of general thievery and mischief, where wedding guests steal chickens (the reason for the term kury) and other small food stuffs from any house in the village, bring them to the groom's house, and prepare and consume them. Sometimes wedding guests "attack" all those who chose to return to normal life instead of continuing the wedding celebration. They sneak into their homes, remove gates from hinges, hide equipment, and commit other pranks. The most popular form of post-wedding revelry is the tsyhanshchyna like the one I witnessed in 
Hrechkivka, Smilians'kyi raion, Cherkas'ka oblast on August 23, 1998. We were driving down the street when we noticed people in costume. At the gate leading into one of the yards there was a man dressed as a doctor. He would administer medical "aid" to anyone entering and collect a fee. The "aid" consisted of taking the guest's temperature with a broom handle "thermometer," "injecting" him or her with water, and then applying iodine/lipstick, thus marking all who had been subjected to the entrance ritual. Inside the yard there were many people, a few in costume, and many quite inebriated. A meal was served which we did not attend. We joined the party several hours later as they were walking down the street. Several young men were pulling a decorated cart in which were seated the parents of the bride. The groom, we were told, was an orphan. If this had not been the case, his parents, would have been the first to suffer a cart ride. The cart and the men/horses were accompanied by a large procession, many of whom were now in costume. Some were dressed as gypsies, the source of the term tsyhanshchyna. Several were cross-dressed and others were dressed in rags or simply had on extravagant makeup. As this procession headed down the street, the cart was intentionally bounced up and down or pulled over the roughest available terrain. Every-so-often, the men/horses would "rear up" and someone would announce that they needed a drink of water/horilka. When the procession encountered anyone who was not part of the wedding party, one of the costumed revelers would offer the bystanders food and horilka and receive in return a small gift for the bridal couple. The procession headed down to the river. With some effort, the cart was pulled down the bank and into the water where it was overturned, dumping the bride's parents into the stream. Since the water was shallow at that spot, several men attacked the couple, especially the father, dousing him, trying to push him into deeper water, or trying to get him to fall so that he would get completely wet. The dunking of the parents was soon followed by general pushing and shoving, attempts to get people into the water with as much of their attire on as possible. Many people, and especially children, simply disrobed to their underwear and went swimming.

The tsyhanshchyna may seem frivolous and raucous with the result that, during Soviet times, authorities exerted great pressure on people not to include it in weddings, objecting especially to things like the head tractor driver cavorting around the village in drag.(5) Nonetheless, it is an important and necessary part of the wedding, as its persistence despite Soviet censure shows. For one thing, as Victor Turner, V. Ia. Propp and others have pointed out, a period of license exists in all meaningful ritual, providing tension release and balance to the solemnity, and sealing the serious rite with the magic of laughter.(6) For another, there are many important and serious components to the tsyhanshchyna. The abuse of the parents has elements of sacrifice for crop fertility. What is done to 
the parents combines ritual lowering of people who normally assume a high and powerful position with affirmation of the value of parents, for only something that is truly precious can be deemed worthy of sacrifice.

Turner argues that ritual is characterized by anti-structure; it is a period when the normal order of things is reversed. The anti-structure permitted in ritual produces catharsis and has a powerful emotional impact. Turner distinguishes two types of rituals: life-cycle rites, of which the wedding is one, and calendary rites, such as Christmas and New Years. According to Turner, the two types of rituals are distinguished by the type of anti-structure which occurs in each. In life-cycle rituals, a person is elevated to a new status. The ritual process of elevation, however, includes a ritual humiliation or lowering of the initiate, before he or she is inducted into higher status. This humbling permits a more potent experience of elevation; it bonds the initiates to one another, and it gives the person going through the rite a better understanding of those who have not been elevated and of the difficulties of life. The ritual lowering of the bride and groom in Ukrainian weddings occurs during the various meals when their friends taunt each other and the couple with insulting and sometimes sexually explicit songs. While life cycle rituals are aimed at people, calendary rites are supposed to affect the outside world and often have something to do with magic that is supposed to insure crop fertility and a good harvest. In calendary ritual, reversal affects everyon: not just select individuals going through marriage, or initiation, or whatever the rite may be. People in high positions humble themselves while people in low positions receive special attention and honor. Actions normally prohibited are condoned. In Ukraine, for example, people are allowed to hit each other on the Sunday before Easter (called Pussywillow Sunday, Verbna nedilia) and the blows with the pussywillow branches are supposed to affect the health of those struck and the fertility of their crops. Normally boys are more aggressive than girls, but girls attack boys during the midsummer holiday (Zeleni sviata) and throw them in the river, again for the same purpose of high crop yield. Cross-dressing, pranks, and thievery are practiced during the winter holidays Rizdvovy sviata. The reversals characteristic of calendary rites, besides contributing to crop fertility, are supposed to ease some of the pressures which normal strictures create by allowing indulgence in their opposites.

Interestingly, the tsyhanshchyna, while part of a life-cycle ritual, has many of the traits of calendary rites. It is a world of anti-structure with easily identifiable elements of reversal. Gypsies, normally considered lowly outcasts, rule. Where most of the time there are clear gender distinctions, during the tsyhanshchyna people cross-dress. Often the parents are made to dress in each other's clothes. Although I did not see this, I have been told that sexual "apparati," usually made out of fruits 
and vegetables, are attached to the parents and sometimes rigged with strings which cause them to move. Behavior which is normally severely chastised (immodesty, theft) is the norm. And, of course, parents, people normally accorded respect and obedience, are mocked and abused.

There is more going on in the tsyhanshchyna than just tension release. The anti-structure features listed above are not selected at random. Many are clearly related to the wedding. It is not necessary to explain how sexuality is part of the wedding and how the immodesty of cross-dressed parents with moving sexual "parts" might acknowledge and express the tension between the demands for sexual restraint under everyday circumstances and sexual activity on the wedding night. The gypsies after whom the tsyhanshchyna is named also reveal a wedding problem. As gypsies are considered outsiders, wanderers alien to the village social structure, so the bride is an outsider who suddenly enters the groom's household. As gypsies are believed to steal and wedding revelers are expected to do so during the tsyhanshchyna, so there is a feeling of financial loss in the wedding exchange. The abuse of the parents does not involve random acts of disrespect. To a certain extent, the parents go through a life cycle ritual when their children marry and receive an elevation in their status as a result. In the weddings I attended, the couples were going to move in with the parents of the groom after the wedding, expect in the case where the groom was an orphan and, in that case, they were planning on joining the household of the bride's parents. This was supposed to increase the prestige and prosperity of the households. Thus, a certain amount of ritual humiliation would be appropriate to the parents because they, like the couple, will experience some status elevation.

But the tsyhanshchyna cannot be explained by its connections to the wedding alone for it resembles calendary ritual and crop fertility magic to a significant degree. As already mentioned, the reversals of the tsyhanshchyna affect not just individuals, but the whole community. More important, the tsyhanshchyna has a sacrificial quality. The river dunking which I witnessed is a fairly common multiform of the post-wedding attack on parents. Its sacrificial quality becomes apparent in the context of other multiforms. There is a great deal of water and fire symbolism, as would be appropriate for sacrificial acts connected to crop fertility. My interviewees told me about lowering parents down well shafts, about driving the cart with the parents through bonfires made of straw; I saw a photograph of such an incident. One person told me that when he, as a godparent, stood in for the deceased father, he and the groom's mother were dumped into a patch of nettles and nettles, because they "burn," are like fire.(7) In one account, the well method produced an actual sacrifice. The man being lowered down the shaft became entangled in the ropes by which he was suspended and was strangled. Several people said that the parents were taken to the local garbage dump and deposited 
there. While this is not a particularly glorious form of sacrifice, the idea that the parents are to be gotten rid of during the tsyhanshchyna is so close to the surface that it was actually articulated by several of the interviewees, most of whom added that this was done because a new couple now existed and the older couples were no longer necessary.

In addition to elements of fire and water sacrifice, vegetation symbolism was in abundance. I have already mentioned that opposite sex "apparati" were attached to the parents. It is significant that all informants said these had to be made out of squash or eggplant for the mother and melons for the father. If sex were the only concern, items other than fruits and vegetables could be used. In the tsyhanshchyna I witnessed, the parents were draped in garlands of leaves, very much like the king and queen of spring or fall agrarian festivals. Thus the contention between the tsyhanshchyna and vegetation was made by the villagers themselves, though probably not on a conscious level.

My informants were not aware of the sacrificial quality of their attacks on the parents of the bride and groom and no one mentioned the connection to crops. As far as they were concerned, this was all great fun; as well as an occasion to eat and drink some more. What is done to the parents, however, seems to accomplish more than counterbalancing the solemnity of the wedding. The tsyhanshchyna offers the parents up as a sacrifice, perhaps not getting rid of them, as tossing them out in the garbage would suggest, but subjecting them to water and fire, typical symbols of vegetation and other fertility. For a sacrifice to be effective, the item destroyed must be one of value and thus the tsyhanshchyna confirms the power of the parents as well as subverting it. Furthermore, what is done to parents in a Ukrainian wedding shows that human life is inextricably connected with the cosmos. Important life cycle rituals like the wedding extend their ritual power beyond the couple, the family, and even the village, to influence the course of nature. In Ukrainian belief, the wedding is a central rite in the life of an human being and all people must wed. This is confirmed by the existence of a death wedding, a funeral ceremony celebrated as a marriage rite, which is performed for young people who die before they have a chance to marry. It is confirmed also by the material presented here where symbolism from agrarian ritual and crop fertility magic is incorporated into the marriage rite and the occasion of the wedding is used to influence all of life, that of the couple, that of their families, the village, and the world of nature.

\section{NOTES}

1. For their help with collecting, I thank Halyna Kornienko and Natalia Havryliuk. I also used the archival resources of the Institute of Folklore, Ethnography, and Folk Art in Kyiv and for her guidance in using this archive, I thank Halyna Dovzhenok. For published sources on the the wedding see: Hnat 
Tantsiura, Vesillia v seli Ziatkivtsiakh, Kyiv: redaktsia chasopysu "Narodoznavstvo," 1998, Vesillia u dvokh knyhakh, ed. M.M. Shubravs'ka and O.A. Pravdiuk, Kyiv: Naukova Dumka, 1970, and Pavlo Chubyns'kyi's Obriady: Rodiny krestiny, svad'ba, pokhorony, volume 4 of Iugo-zapadnyi otdel russkogo imperatorskggo geograficheskogo obshchestva: Materialy i izsledovaniia, 1877.

2. Photographs from the wedding of Halyna Matlash Kapas'.

3. In s.Kopachiv, Obukhivs'kyi r-n, Kyivs'ka obl. Halyna Afanasivna Habata told me that while city folk all ask about the custom of the pumpkin, this existed in theory only. There were no requests for a bride that she knows of where a pumpkin was presented instead of a loaf of bread. Recorded 11-1698.

4. The kerchief custom was collected from Liubov Danylivna Lutchenko, s. Bolhodukhiv, Chornobais'kyi r-n, Cherkas'ka obl., 8-8-98.

5. Valentyna Kyrylivna Borysenko, m.Kyiv, told me this on October 23,1998 . Borysenko did extensive collecting of material on weddings and published Vesil'ni zvychaii ta obriady na Ukraïni: istoryko-etnohrafichne doslidzhennia, Kyiv: Naukova dumka, 1988. She said that both she and her informants had to conceal the existence of the tsyhanshchyna.

6. Victor Turner, The Ritual Process: Structure and Anti-Structure. (Ithaca, New York: Comell University Press, 1969). V. Ia. Propp, Russkie agrarnve prazdniki. (1963; reprint, Sankt-Peterburg: Azbuka, 1995).

7. Mykhailo Dymytrovych Koval', s. Velykii Khutir', Drabivs'kyi r-n, Cherkas'ka obl., 8-14-98. 